\title{
Wetland management: preparing for climate and coastal change using adaptation pathways
}

\author{
Peter Gell ${ }^{\mathrm{a}, \mathrm{b}, 1}$

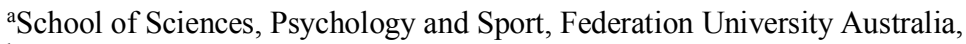 \\ ${ }^{b}$ Diponegoro University, Semarang, Indonesia
}

\begin{abstract}
Freshwater ecosystems are among the most threatened in the world. The list of threatened species in freshwater ecosystems is greater than that in terrestrial or marine systems and freshwater vertebrates are particularly at risk. Freshwater wetlands have evolved in coastal zones protected from tidal influence by barrier dune systems. Similarly, estuaries have supported zones of low salinity diluted by flows from land, but water resource development has limited these flows and driven ecological change in estuarine systems. These historical uses of river flows, and the impacts of catchment development on water quality and yields, have combined to threaten coastal wetland ecosystems. They are now under increasing threat through climate change driven alterations to hydroclimatic conditions, as well an rising sea levels which risk inundation of low lying coastal regions, including wetlands. Coastal freshwater systems offer considerable ecosystem services to human systems and host significant biodiversity assets. These have been subjected to increased risk through catchment and coastal development, but are now acutely threatened through changed river flows and elevated sea levels that result from climate change. Managing these systems requires an adaptation pathways approach that accommodates human needs, and society's obligations to global biodiversity.
\end{abstract}

\section{Introduction}

Freshwater ecosystems have been identified as being exposed to great risk, owing to factors such as pollutants and river regulation, for many decades. Dudgeon and others [1] identified the five major threats to aquatic biodiversity (Table 1). There are many more species at risk in freshwater systems than in either terrestrial or marine settings, and this is particularly the case for freshwater vertebrates [2]. More recently Reid et al. [3] recognised these major threats as being persistent, and identified twelve emerging risks to freshwater biodiversity systems (Table 1) including the risk of synergistic effects whereby one or more risks interact to create unexpected challenges for management. The challenge for freshwater management still lies very much in the sphere of the legacy effects of past land clearance, waterway modification and human water consumption however global warming will lead to critical impact associated with changing climates as well as rising sea levels. This will ensure the

\footnotetext{
${ }^{1}$ Corresponding author: p.gell@federation.edu.au
} 
human influence on aquatic systems has a global reach, but impacts will be a consequence of the degree to which each of these stressors translates in a local context.

\section{Catchment development}

The impact of humans on aquatic systems can be traced across thousands of years by using the chemical and biological archives preserved in wetland sediments. Human impacts intensified from soon after the establishment of sedentary societies in the early Holocene and impacts such as heavy metal pollution, sedimentation, salinisation, eutrophication etc. can be traced back millennia [4]. In places that were settled by humanity early there is a pattern of gradual intensification of impact whereas in regions where humans arrived late, with a relatively sophisticated technology, impacts were more abrupt.

Table 1. Major [1] and emerging [3] threats to freshwater biodiversity

\begin{tabular}{lll}
\hline MAJOR THREATS & EMERGING THREATS & \\
\hline $\begin{array}{l}\text { Overexploitation } \\
\text { Water Pollution }\end{array}$ & Changing Climates & Engineered Nanomaterials \\
$\begin{array}{l}\text { Flow Modification } \\
\text { Destruction or degradation } \\
\text { Habitat }\end{array}$ & efommerce and Invasions & Microplastic Pollution \\
Invasion by Exotic Species & Infectious Diseases & Light and Noise \\
& & Freshwater Salinisation \\
& $\begin{array}{l}\text { Expanding Hydropower } \\
\text { Emerging Contaminants }\end{array}$ & $\begin{array}{l}\text { Declining Calcium } \\
\text { Cumulative Stressors }\end{array}$ \\
\hline
\end{tabular}

The rate of impact of all persistent threats increased substantially after WWII under the 'Great Acceleration' [5] that has been used to delineate the Anthropocene, a new epoch within which the human imprint is now a force in the functioning of the Earth [6]. While some nations (e.g. USA) are decommissioning many major impoundments [7] the volume of water in storage exceeds all that in the world's rivers five-fold [1] and abstraction and flow changes have substantially reduced the number and extent of wetlands worldwide [8]. Habitat degradation and water quality changes have led to widespread degradation of those that remain, leading to critical transitions in some situations [9] that lock in mechanisms that make the restoration challenge even greater. International treaties such as the Ramsar Convention and the ChinaAustralia Migratory Bird Agreement rely heavily on co-operative international commitment yet many species remain in decline.

\section{Climate change}

The high freshwater biodiversity documented today experienced high amplitude climate variations through at least the last glacial-interglacial cycle suggesting it has high levels of resistance, and resilient, to millennial scale climate change. Industrial pollution however, has led to $\mathrm{CO}_{2}$ concentrations likely reaching levels greater than any since the Pliocene \{10] which is consistent with global temperatures at least $2^{\circ} \mathrm{C}$ greater than the pre-industrial baseline. While there is considerable lag in the response, such temperatures will lock the planet into sea levels rises in the order of $50-140 \mathrm{~cm}$ [11] or more [10]. The increased energy in the system likely will lead to more intense tropical precipitation and substantial reductions in Mediterranean zone rainfall. The local impact of these hydroclimatic shifts will be greatest on intermediate rainfall zones yet low lying inundation is likely to be widespread in zones 
with shallow coastal profiles, particularly those already experiencing inundation due to other factors such as land subsidence following groundwater abstraction.

\section{Synergistic effects}

Both climate and catchment changes will contribute, together, to some threats raising the bar for management intervention. Hazardous algal blooms for example are forecast to increase as human populations continue to release nutrients loads into waterways. This will be exacerbated by the regulation of flow and abstraction of water as high water retention time advantages the proliferation of cyanobacteria over other autotrophs. However, cyanobacteria and also more competitive at higher temperatures and also produce more biomass under higher atmospheric concentrations of $\mathrm{CO}_{2}$ [12]. Further, water abstraction reduces the flushing of tidal salts by rivers at the coast likely leading to even greater penetration of marine waters under higher sea levels $[13,14]$.

\section{The Murray Darling Basin}

The state of the Murray Darling Basin highlights many of these persistent and emerging threats. The Basin received $400 \mathrm{M} \mathrm{m}^{3}$ of sediment from Victorian gold mining sluices between 1850 and 1880 [15] and so it suffers substantial legacy and ongoing (catchment erosion, riverbank collapse) impacts on water quality. While its waters were abstracted for (European) industrial use through the $\mathrm{C} 19^{\text {th }}$ this increased substantially from the $1950 \mathrm{~s}$ whereby up to $80 \%$ of flow was abstracted before recent interventions. This flow now passes many impoundments including a series of barrages at the mouth designed to resist the inflow of tidal waters. The Basin's wetlands are impacted by both native, and exotic invaders such as Carp, Mosquito Fish and bulrush (Typha spp.) and macrophyte-rich wetlands have lost critical habitat owing to too much [16], and too little water depending on circumstance. The system suffers from low flows, high turbidity, eutrophication [17], hazardous algal blooms extending many hundreds of kilometres and massive fish kills [18]. Climate scenarios reveal high likelihood of considerably lower catchment runoff and water yields [19] and the increased penetration of sea water into the low lying hinterland near the river mouth [20].

Little over 150 years of catchment development has driven to basin's waterways to a tipping point [21] and the nation is now investing \$13B (AUD) under the Murray Darling Basin Plan [22] to restore its waterways. The focus of this Plan is to purchase water ( $2500 \mathrm{GL} / \mathrm{yr})$ from agricultural uses for environmental flows, supplemented by savings from infrastructure designed to reduce evaporative losses. This prioritisation of water volume as the means of rehabilitating stressed waterways overlooks many other of the persistent and emerging threats [23] and levels great opportunity cost on the primary industry sector and regional communities.

\section{Adaptation pathways}

The drivers of wetland degradation has a long history and in many instances the impacts we witness today have been foreseeable for many decades. In the absence of serious, collaborative attempts to mitigate global carbon emissions the earth is committed to a certain level of sea level rise. Recognising this an approach to implement staged measures to adapt to an ever rising sea on the River Thames and the city of London was proposed [24, 25]. It is 
clear that the immediate implementation of measures and barriers to resist a $1.5 \mathrm{M}$ sea level rise would be premature, given present rates being at $\sim 5 \mathrm{~mm} / \mathrm{yr}$, and this would level considerable adaptation cost on the present British tax payers. Rather than level the cost of adaptation to reduced catchment runoff, compromised water quality and invasive species on the present generation of Murray River water users, such a staged approach could also be implemented which examines the timing of implementation of measures in a staged process thereby spreading the financial impact across generations [25]. Such a planned approach allows decision makers to assess the trade-offs between environmental, economic and social interests and avoids the perverse outcomes of a cap-and-trade market-based approach. Commitment to such a program requires acceptance of the pathway itself, and its scientific underpinnings, by the communities that will bear the cost of the management investment and the shift from the current path.

\section{Conclusion}

Human societies have had considerable impact on the world freshwater ecosystems and the rate of impact has accelerated in recent decades. These impacts will continue to increase, supplemented by climate change and associated elevated sea levels, and the synergistic effects that arise from the interaction between both persistent and emerging threats. These systems provide humanity with vast resources and ecosystem services and their ongoing demise will impact society negatively. To mitigate this pressure on the function of freshwater socio-ecological systems, and to avoid critical transitions that lead to depleted ecological states, society needs to map out the drivers of degradation and implement a pathway of measures to create a just existence for present and future generations.

\section{References}

1 D. Dudgeon, A.H. Arthington, M.O. Gessner, Z. Kawabata, D.J. Knowler, C. LeVeque, R.J. Naiman, A-H. Prieur-Richard, D. Soto, M.L.J. Staissny, C.A. Sullivan, Biol. Rev. 81, 163-182 (2008)

2 F. He, C. Zarfl, V. Bremerich, J.N.W. David, Z. Hogan, G. Kalinkat, K. Tockner, S.C. Jähnig, Global Ch. Biol. 25, 3883-3892 (2019)

3 A.J. Reid, A.K. Carlson, I.F. Creed, E.J. Eliason, P.A. Gell, P.T.J. Johnson, K.A. Kidd, T.J. MacCormack, J.D. Olden, S.J. Ormorod, J.P. Smol, W.W. Taylor, K. Tockner, J.C. Vermaire, D. Dudgeon, S.J. Cooke, Biol. Rev. 94, 849-873 (2019)

4 N. Dubois, E. Saulnier-Talbot, K. Mills, P. Gell, R. Battarbee, H. Bennion, S. Chawchai, X. Dong, P. Francus, R. Flower, D.F. Gomes, I. Gregory-Eaves, S. Humane, G. Kattel, J-P. Jenny, P. Langdon, J. Massaferro, S. McGowan, A. Mikomägi, N. Nguyen, A.S. Ratnayake, M. Reid, N. Rose, J. Saros, D. Schillereff, M. Tolotti, M., B. Valero-Garcés, Anthropocene Rev. 5, 28-68 (2018)

5 Millennium Ecosystem Assessment, Ecosystems and human well-being: Wetlands and water synthesis. (World Resources Institute, Washington, DC, 2005)

6 W. Steffen, W. Broadgate, L. Deutsch O. Gaffney, C. Ludwig. Anthropocene Rev. 2, 81-98 (2015)

7 J.E. O'Connor, J.J. Duda, G.E. Grant, Science 348, 496-497 (2015)

8 N.C. Davidson, C.M. Finlayson, Mar. Freshw. Res. 69, 1525-1533 (2018) 
9 R. Wang, J.A. Dearing, P.G. Langdon, E. Zhang, X. Yang, V. Dakos, M. Scheffer,. Nature 492, 419-422 (2012)

10 H. Fischer, K.J. Meissner, A.C. Mix, N.J. Abram, J. Austermann, V. Brovkin, E. Capron, D. Colombaroli, A-L. Dabiau, K.A. Dyez, T. Felis, S.A. Finkelstein, S.L. Jaccard, E.L. McClymont, A. Rovere, J. Sutter, E.W. Wolff, S. Affolter, P. Bakker, J.A. Bellesteros-Canovas, C. Barbante, T. Caley, A.E. Carlson, O. Churakova, G. Cortese, B.F. Cumming, B.A.S. Davis, A. de Vernal, J. Emile-Gray, S.C. Fritz, P. Gierz, J. Gottschalk, M.D. Holloway, F. Joos, M. Kucera, M-F. Loutre, D.J. Lunt, K. Marcisz, J. Marlon, P. Martinez, V. Masson-Delmotte, C. Nehrbass-Ahles, B.L. Otto-Bliesner, C.C. Raible, B. Risebrobakken, M.F. Sánchez Goñi, J.S. Arrigo, M. Sarnthein, J. Sjolte, T.F. Stocker, P.A. Velasquez Alvarez, W. Tinner, P.J. Valdes, H. Vogel, H. Wanner, Q. Yan, Z. Yu, M. Ziegler, L. Zhou, Nature 11, 474-485 (2018).

11 S. Rahmsdorf, Science 315, 368- 370 (2007)

12 P.M. Visser, J.M.H. Verspagen, G. Sandrini, L.J. Stal, H.C.P. Matthijs, T.W. Davis, H.W., Paerl, J. Huisman, J.. Harmful Algae 54, 145-159 (2016)

13 E.R. Herbert, P. Boon, A.J. Burgin, S.C. Neubauer, R.B. Franklin, M. Ardon, K.N. Hopfensberger, L.P.M. Lamers, P. Gell, Ecosphere 6(10), 1-43 (2015)

14 B. Thom, E. Rocheta, C. Steinfeld, N. Harvey, J. Pittock, P. Cowell, Riv. Res. Appl. 36, 656-667 (2020)

15 P. Davies, S. Lawrence, J. Turnbull, I. Rutherfurd, J. Grove, E. Silvester, D. Baldwin, M. Macklin, M. Anthropocene 21, 1-15 (2018)

16 P.A. Gell, Riv. Res. Appl. 36, 620-629 (2020)

17 P. Gell, M. Reid, Front. Ecol. Evol. 4: art \# 16 (2016)

18 R. Vertessy, D. Barma, L. Baumgartner, S. Mitrovic, F. Sheldon, N. Bond, Independent Assessment of the 2018-19 fish deaths in the lower Darling. Minister for Agriculture and Water Resources (Canberra, 2019)

19 CSIRO, Water Availability in the Murray-Darling Basin. A report to the Australian Government from the CSIRO Murray-Darling Basin Sustainable Yields Project. (CSIRO, 2008)

20 A.M. Helfensdorfer, H.E. Power, T.C.T. Hubble, Nature Scientific Reports 9, art 2667 (2019)

21 W.F. Laurance, B. Dell, S.M. Turton, M.J. Lawes, L.B. Hutley, H. McCallum, P. Dale, M. Bird, G. Hardy, G. Prideaux, B. Gawne, C.R. McMahon, R. Yu, J-M. Hero, L. Schwarzkopf, A. Krockenberger, M. Douglas, E. Silvester, M. Mahony, K. Vella, U. Saikia, C-H. Wahren, Z. Xu, B. Smith, C. Cocklin, Biol. Cons. 144, 1472-1480 (2011)

22 MDBA, MDBA Basin Plan. (Murray Darling Basin Authority, Canberra, 2013)

23 L.J. Baumgartner, P. Gell, J.D. Thiem, C.M. Finlayson, N. Ning, Riv. Res. Appl. 36, 645-655 (2020)

24 R.L. Wilby, S. Dessai, Weather 65, 180-185 (2010)

25 P.A. Gell, M.A. Reid, R.L.Wilby, Riv. Res. Appl. 35, 1291-1301 (2019) 